\title{
Assessment of procurement capacity challenges inhibiting public infrastructure procurement
}

DOI:

10.1108/BEPAM-02-2018-0038

\section{Document Version}

Accepted author manuscript

Link to publication record in Manchester Research Explorer

\section{Citation for published version (APA):}

Manu, P., Mahamadu, A. M., Booth, C., Olomolaiye, P., Ibrahim, A. D., \& Coker, A. (2018). Assessment of procurement capacity challenges inhibiting public infrastructure procurement: A Nigerian inquiry. Built Environment Project and Asset Management, 8(4), 386-402. https://doi.org/10.1108/BEPAM-02-2018-0038

\section{Published in:}

Built Environment Project and Asset Management

\section{Citing this paper}

Please note that where the full-text provided on Manchester Research Explorer is the Author Accepted Manuscript or Proof version this may differ from the final Published version. If citing, it is advised that you check and use the publisher's definitive version.

\section{General rights}

Copyright and moral rights for the publications made accessible in the Research Explorer are retained by the authors and/or other copyright owners and it is a condition of accessing publications that users recognise and abide by the legal requirements associated with these rights.

\section{Takedown policy}

If you believe that this document breaches copyright please refer to the University of Manchester's Takedown Procedures [http://man.ac.uk/04Y6Bo] or contact uml.scholarlycommunications@manchester.ac.uk providing relevant details, so we can investigate your claim.

\section{OPEN ACCESS}




\section{Built Environment Project and Asset Management}

DOI: 10.1108/BEPAM-02-2018-0038

\section{Assessment of Procurement Capacity Challenges Inhibiting Public Infrastructure Procurement: A Nigerian Inquiry}

Patrick Manu ${ }^{1 *}$, Abdul-Majeed Mahamadu ${ }^{1}$, Colin Booth ${ }^{1}$, Paul Olomolaiye ${ }^{1}$, Ahmed Ibrahim², Akinwale Coker ${ }^{3}$.

${ }^{1}$ Faculty of Environment and Technology, University of the West of England, Bristol, BS16 1QY, UK.

${ }^{2}$ Department of Quantity Surveying, Ahmadu Bello University, Zaria, Nigeria.

${ }^{3}$ Department of Civil Engineering, University of Ibadan, Ibadan, Nigeria.

${ }^{*}$ Corresponding author: Patrick Manu

Email: Patrick.Manu@uwe.ac.uk

\section{Acknowledgement}

Appreciation is extended to the United Kingdom Department for International

Development (DfID) for funding this research through the Urbanisation Research Nigeria Programme. 


\section{ABSTRACT}

Purpose: Public procurement capacity is composed of three facets: individual; organizational; and an enabling national environment which encapsulates national legislation, policies, and institutional arrangements that can facilitate or hamper the effectiveness of procurement. This study investigated the extent to which procurement capacity challenges in the national environment affect the effectiveness of infrastructure procurement by public agencies in Nigeria.

Design/methodology/approach: 30 procurement capacity challenges drawn from literature were operationalized in a survey of infrastructure procurement personnel in different tiers of public agencies (i.e. local and state government) in order to ascertain the critical challenges affecting the effectiveness of infrastructure procurement. The survey yielded 288 responses, which were analysed using descriptive statistics, one sample ttest and independent samples t-test.

Findings: Challenges related to transparency, integrity and accountability are amongst the topmost challenges adversely affecting the effectiveness of public infrastructure procurement. There is limited difference in the extent to which the challenges affect the effectiveness of infrastructure procurement in different tiers of public agencies in Nigeria.

Originality/value: Whilst various procurement capacity challenges have been identified in the extent literature, this study has shown that an assessment of their effect on the effectiveness of infrastructure procurement could reveal valuable insights regarding the status of public infrastructure procurement within a country, particularly countries in subSaharan Africa and other developing regions where there is acute infrastructure deficits. Such insights could inform appropriate infrastructure procurement reforms by policy makers, procurement entities, and infrastructure funders. 
Keywords: Procurement; procurement capacity; infrastructure; developing countries; survey, sub-Saharan Africa.

Manuscript Type: Research paper

\section{INTRODUCTION}

According to the United Nations Economic and Social Council (2016), over half of the population in sub-Saharan Africa live in slum-like conditions with limited access to suitable housing and the associated municipal service infrastructure. Generally, infrastructure for the delivery of municipal services is thought to account significantly for the productivity differences between high-income and low-income countries (Parente and Prescott, 2000). Despite governmental recognition of the role of infrastructure and consequent investments, the infrastructure deficits of countries in sub-Saharan Africa remain high (see Foster and Pushak, 2011; Presidential Infrastructure Coordinating Commission, 2012; AfDB, 2013; Veitch, 2014). Procurement of infrastructure remains paramount. In spite of procurement reforms in several countries in the sub-Saharan African region over the years, procurement capacity deficiencies still persist (World Bank, 1995, 2000; Agu and Onodugo, 2009; Addo-Duah et al., 2014; de Mariz and Abeillé; 2014).

Public procurement capacity is multi-faceted including individual, organizational and environmental elements (United Nations Development Programme (UNDP), 2006). The environmental facet relate to an enabling national environment which encapsulates the national legislation, policies and the broader institutional culture required for effective procurement (UNDP, 2010). The environmental factors border on the institutional arrangements related to public financial management, civil service, education and other civil society participation (Fayomi, 2013; World Bank, 2013; Ndercaj and Ringwald, 2014). Furthermore, they often describe the role of policy, power relations and social norms in 
addition to legislation and regulatory reforms (Jensen and Refsgaard, 2008). The enabling environment is vital to the procurement function of individual procurement personnel and the organisations within which they function. In order therefore to explore infrastructure procurement capacity building, there is a need to understand the extent to which factors relating to the environmental facet inhibit the effectiveness of infrastructure procurement by public organisations. Despite the availability of studies that have highlighted public procurement challenges in countries in sub-Saharan Africa (e.g. Fayomi, 2013; World Bank, 2013; Addo-Duah et al., 2014; de Mariz, and Abeillé, 2014), the extent to which procurement capacity challenges related to the environmental facet affect the effectiveness of infrastructure procurement by governmental organisations has received limited research. This study investigated the extent to which procurement capacity challenges aligned to an enabling environment affect the effectiveness of infrastructure procurement within the context of Nigeria.

The article is structured as follows: a discussion of the status of infrastructure and public procurement in Nigeria; and a review of the procurement capacity literature to identify issues pertinent to the environmental facet of procurement capacity. The research strategy adopted is then presented before the findings, discussion, and concluding remarks.

\section{STATE OF NIGERIA'S INFRASTRUCTURE AND PUBLIC PROCUREMENT}

Sub-Saharan Africa is one of the regions with the poorest people in the world (United Nations Economic and Social Council (2016). Access to various types of infrastructure remains sparse (United Nations Economic and Social Council (2016). Although Nigeria is the largest economy in Africa (World Bank, 2017), the state of its infrastructure still mirrors the situation within its region. Infrastructure for power generation, transport, 
education, sanitation, health care, housing and other services is inadequate. For instance, housing shortage is estimated at 17 million units (Veitch, 2014) and approximately half of the rural population live more than $2 \mathrm{~km}$ away from an all-season road (AfDB, 2013). Access to water and sanitation facilities is also low (Foster and Pushak, 2011).

Over the years, there have been efforts to address the infrastructure deficits through public procurement which incorporates "all actions from planning and forecasting, identification of needs, sourcing and solicitation of offers, evaluation of offers, review and award of contracts, contracting and all phases of contract administration until delivery of the goods, the end of a contract, or the useful life of an asset" (United Nations Office for Project Services (UNOPS), 2014, p.24). Whilst public procurement in Nigeria has undergone reforms (e.g. Due Process Policy (Ocheni and Nwankwo, 2012)), a prominent landmark in public procurement reforms in Nigeria has been the introduction of the Public Procurement Act 2007 (PPA 2007). The PPA 2007 has 13 parts and 61 sections with the broad aim of dealing exhaustively with all issues related to transparency and integrity in public procurement. The PPA 2007 requires the establishment of a National Council on Public Procurement (NCPP) as an apex regulatory body with a Bureau of Public Procurement (BPP) as its administrative secretariat. The primary objectives of the BPP include: harmonization of procurement practices and policy; institution of due process in procurement; introduction of honesty, accountability and transparency in procurement; standardization of procurement procedures; procurement management; and performance evaluation. The key functions required of the BPP include: regulation of public procurement functions of procuring agencies and institutions; certification of procurement entities; monitoring of procured projects; coordination of training and capacity building; and general oversight and advisory functions. Collectively the NCPP and the BPP are to supervise and regulate all public procurement activities together with 
the participation of civil society. Despite the establishment of the BPP, it is reported that the NCPP is not fully functional (World Bank, 2013). According to Adewole (2014) most states have not enacted the PPA 2007 despite Federal government, donor agency and civil society organisations promotion.

On the back of public procurement reforms, some benefits have been attained. Amongst the reported benefits attained are: reinstatement of wrongly awarded public contracts to deserving bidders; good governance of public funds and assets; reduction in corruption; improved transparency and accountability of government; and general restoration of public confidence in public procurement (Fayomi, 2013). Despite these benefits, procurement within the public sector is still fraught with capacity challenges.

\section{PROCUREMENT CAPACITY}

The Organisation for Economic Co-operation and Development (OECD) (2006, p. 12) defines capacity as "the ability of people, organisations/institutions and society as a whole to successfully manage their affairs". In relation to procurement capacity, UNDP (2010) describes procurement capacity development as the process through which individuals, organisations and societies obtain, strengthen, and maintain the capabilities to set and achieve development objectives. Public procurement capacity can be viewed as comprising three facets: individual (i.e. the skills, knowledge and experience of personnel); organizational (i.e. the policies, procedures and systems within an organization that support procurement functions); and an enabling environment.

The enabling environment aspect, which is pertinent to this study, is a term used to describe the broader national system within which procurement personnel and organisations function, and it facilitates or hampers their performance (Ndercaj and Ringwald, 2014). Whilst this aspect of procurement capacity may not be easy to grasp 
tangibly, it is central to the understanding of capacity issues at the individual or organization level. The environmental level relates to the availability of legislation, policies as well as broader institutional culture required for effective procurement (UNDP, 2006; Jensen and Refsgaard, 2008). Capacity at the environmental level also include power relations and social norms which govern public procurement mandates, priorities, modes of operation and civic engagement across different parts of society (Jensen and Refsgaard, 2008). The OECD-DAC tool for capacity assessment also focusses on four pillars that can be applied to the environmental aspect of procurement capacity assessment namely: legislative and regulatory framework; institutional framework and management capacity; procurement operations and market practices; and integrity and transparency of the procurement institutions (OECD and World Bank, 2004). Generally environmental level capacity issues are also influenced by the interactions between public financial management systems, legal and judiciary service, audit services, anticorruption agencies, civil service, educational institutions, private sector and other civil society agencies (Fayomi, 2013; World Bank, 2013; Ndercaj and Ringwald, 2014). Based on a meta-analysis of procurement studies in sub-Saharan Africa (SSA), Ndercaj and Ringwald (2014) categorized procurement challenges as follows:

- Legislation and regulatory framework - Challenges related to irrelevance of public procurement Acts and frameworks due to rapid and dynamic changes in economy, society and the environment;

- Institutional issues - Challenges related to lack of strong procurement institutions and professionals or inadequate training programs throughout government, private or civil services agencies;

- Operational and management - Challenges related to limited recognition of procurement as a specialist and strategic function; and 
- Control and integrity - Challenges related to inadequate trust, honesty, transparency, integrity, compliance, monitoring, and accountability.

These challenges, some of which have been reported in other procurement studies in Nigeria and other sub-Saharan African countries, in the main are issues that relate to an enabling environment for procurement. Table 1 presents a variety of challenges (drawn from literature) that relate to an enabling environment for procurement. The challenges have also been clustered along the lines of Ndercaj and Ringwald's (2014) categorisation and the pillars of the OECD-DAC capacity assessment tool (OECD and World Bank, 2004). Based on this categorisation, it can be seen that the institutional challenges are the most common, followed by challenges related to control, integrity and transparency. The operational challenges are the least common. Despite recognition of these challenges within the extant literature, an assessment of the extent to which the adversely impact the effectiveness of infrastructure procurement by public institutions at state and local government levels within the Nigerian context is lacking. Such assessment could enable determination of the critical challenges affecting infrastructure procurement.

\section{[Insert Table 1]}

\section{RESEARCH METHOD}

Based on the research aim a quantitative cross-sectional questionnaire survey was adopted as the method of inquiry. The choice of this strategy was borne out of the need to gauge the effect of challenges related to the environmental facet of procurement capacity. The study undertook a survey of public personnel involved in the procurement of infrastructure.

\section{Design of the Survey}


The first section of the questionnaire solicited background information about respondents and the public institutions they work for. This included their professional role, experience, the types of infrastructure they are involved in their procurement, the type of organization they work for (i.e. state or local government organization) and the location of the organization (northern or southern geopolitical zone). According to Adewole (2014) there are apparent differences in the procurement capacities of organisations, hence the consideration of the type and location of the respondents' organisations. A second section of the questionnaire solicited opinions about the challenges drawn from the literature (Table 1). The respondents were asked to rate the extent to which the challenges adversely affect the effectiveness of infrastructure procurement by the organisations. A 5-point Likert scale (i.e. $1=$ not at all; $2=$ low; $3=$ moderate; $4=$ high; 5 = very high) was used.

\section{Sampling}

The survey for this study was administered among infrastructure procurement personnel within local government authorities' works departments and within state ministries, agencies and institutions in two locations - Kaduna Sate (Northern Nigeria) and Oyo State (Southern Nigeria). The personnel included built environment professionals and personnel who are often involved in the initiation, planning, design, execution, and evaluation phases of municipal infrastructure procurement (e.g. urban/town planners, architects, civil/structural engineers, quantity surveyors, project managers, electrical engineers, and procurement administrators). These two states were selected for being homes to major Nigerian cities (Kaduna City and Zaria in Kaduna State, and Ibadan in Oyo State) and also due to the inadequate state of infrastructure in the states (see Oyo State Government, 2010; Kaduna State Government, 2013). A total of 373 questionnaires were administered by hand delivery to the infrastructure procurement personnel described above over a period of three months (July - September 2016). 288 valid 
questionnaires were returned (i.e. $77.21 \%$ response rate) comprising 117 (from the north) and 171 (from the south).

\section{Data analysis}

Both descriptive and inferential statistics were used in the analysis of data with the aid of IBM SPSS (Version 23) package. One-sample t-test (with test values 1.5, 2.5 and 3.5) was used to explore the levels of impact of the challenges on the effectiveness of infrastructure procurement. From the five-point Likert scale, a test value of 1.5 approximates to 2 on the scale (i.e. "Low" effect). Also, from the five-point Likert scale, a test value of 2.5 approximates to 3 on the scale (i.e. "Moderate" effect), and a test value of 3.5 approximates to 4 on the scale (i.e. "High" effect). The extent of impact of the challenges were thus determined based on variables achieving a statistically significant Mean greater than the test values (Ahadzie et al., 2008; Field, 2013). The independent samples t-tests was also used to explore the existence of statistically significant differences in the perceived effect of the challenges based on the type of organization (local and state) and the location of organization (north and south) of the respondents.

\section{RESULTS}

The results are presented below under two main themes: respondents' demographic information; and effects of procurement challenges on effectiveness of infrastructure procurement.

\section{Demographic Information}

The respondents' role and involvement in infrastructure procurement are shown by Table 2. From the table, the respondents are largely in roles that are related to infrastructure procurement. Additionally, the mean experience in their role is 13.48 years (standard 
deviation $=7.21$ ) and the mean experience in procurement of infrastructure is 9.51 years (standard deviation $=6.166$ ). Overall, from the respondents' demographic profile, it is reasonable to conclude that they are well placed to adequately respond to the subject of inquiry being addressed by the survey. Their responses can thus be regarded as reliable.

$$
\text { [Insert Table 2] }
$$

\section{Effect of Procurement Capacity Challenges}

The research sought to establish the extent to which procurement challenges pertaining to an enabling environment are affecting the effectiveness of infrastructure procurement by public organisations. This was based on respondents' perceptions about the effect of the environmental level challenges shown in Table 1.

Based on a ranking of the challenges by their Mean extent of adverse impact (shown by Table 3), the following were identified amongst the top challenges with the most adverse impact: Political interference and nepotism (Mean $(M)=3.561)$; Corruption and conflict of interest $(M=3.545)$; Inadequate remuneration of procurement professionals $(M=$ 3.414); Ineffective auditing, monitoring and evaluation ( $M=3.376)$; Poor access to information and lack transparency $(M=3.375)$; Lack of motivation and job satisfaction in procurement profession ( $M=3.366)$; Lack of civil society participation $(M=3.364)$; Lack of knowledge and professionalism in public procurement ( $M=3.355)$; Socio-cultural disregard for laws and due process $(M=3.346)$; and Centralized political and governance systems $(M=3.314)$.

Amongst the challenges with the least adverse impact (based on the ranking) are: Lack of capacity within other procuring agencies/entities $(M=3.194)$; Lack of capacity within regulatory institutions $(M=3.167)$; Complexity and lack of detailed national regulations and documentation on procurement $(M=3.139)$; Lack of consideration of social and 
environmental issues in national procurement frameworks and regulations $(M=3.129)$; and Vague and outdated national procurement laws and regulatory frameworks (3.063).

An initial one-sample t-test (with test value of 3.5) to examine whether the Mean score for each challenge is significantly greater than 3.5 (i.e. considered as having at least a "High" effect on procurement effectiveness) revealed no significant results. A subsequent onesample t-test (with test value of 2.5) to examine whether the Mean score for each challenge is significantly greater than 2.5 (i.e. considered as having at least a "Moderate" effect on procurement effectiveness) revealed significant results for all the challenges. This is shown by Table 3. Consequently the one-sample t-test with test value of 1.5 was not needed.

Results of independent-samples t-test performed to explore significant differences in the extent of impact of the challenges by comparison of organization (i.e. local government compared to state government) is summarized in Table 4 . For the sake of brevity on the significant results are shown by Table 4. From the results, Lack of knowledge and professionalism in public procurement $[\mathrm{t}(285)=2.129, p=0.034]$ is the only challenge found to affect the effectiveness of procurement within local government more than state government organisations. Independent-samples t-test to explore differences in perceived effect of the challenges based on location of respondent organization (i.e. north or south Nigeria) did not yield any significant results.

\author{
[Insert Table 3]
}

[Insert Table 4]

\title{
DISCUSSION
}

The analysis revealed some findings which are the focus of this discussion. Whilst it is not surprising that none of the challenges is perceived as having no adverse effect (given 
their mention in the extent literature (Table 1)), overall, it is rather surprising that none of the challenges is perceived as having at least a "high" impact considering that several of them have persistently been reported in literature. This may be a reflection of some of the benefits gained through public procurement reforms (e.g. due process policy). For instance, Fayomi (2013) reported benefits such as: good governance of public funds and assets; reduction in corruption; improved transparency and accountability of government; and general restoration of public confidence in public procurement. Also, according to Adewole (2015), the introduction of the due process mechanism in Oyo State yielded benefits such as: getting best value-for-money in public procurement; enhanced competitiveness and transparency; and money savings.

Interestingly, Political interference and nepotism, and Corruption and conflict of interest were identified as the two topmost environmental capacity challenges by respondents. Furthermore, four of the five topmost challenges have strong relevance to corruption and malpractice specifically related to issues of transparency, integrity and accountability in public procurement (Kolstad and Wiig, 2009; OECD, 2009; Ndercaj and Ringwald, 2014). These four challenges are further aligned to Ndercaj and Ringwald's (2014) control and integrity category of procurement challenges as well as the integrity and transparency pillar of the OECD-DAC capacity assessment tool (OECE and World Bank, 2004). Importantly, the four challenges highlight that transparency, integrity and accountability issues continue to be key areas of concern in Nigeria's public procurement, including the procurement of infrastructure.

Contrary to the view that agencies in lower tiers of government have greater capacity constraints (Agu and Onodugo, 2009; Fayomi, 2013), only one of the 30 challenges was found to adversely affect the effectiveness of procurement by local government 
organisations more than state government organisations (i.e. Lack of knowledge and professionalism in public procurement). Also, the independent-samples t-test revealed no significant differences in the perceived effect of the challenges based on location of respondents' organization. The findings thus seem to suggest that the level of public procurement organization in the national governance structure (i.e. state and local government) and geopolitical location (i.e. south and north of Nigeria) have a limited bearing on the extent of impact of the challenges on the effectiveness of infrastructure procurement by public organisations. This seem to suggests that equal attention may be needed in addressing the impact of the challenges on organisations across state and local government levels, and also across different geopolitical locations (particularly north and south).

Despite the afore mentioned potential benefits of public procurement reforms in Nigeria, the study still signals the prevalence of public procurement challenges which led to the procurement reforms in the first place. The primary drivers of procurement reform in Nigeria and more broadly in developing country contexts include: lack of procurement capacity and knowledge; lack of procurement plans and procedures; and malpractice and corruption (Evenett and Hoekman, 2005; Jensen and Refsgaard, 2008; Ndercaj and Ringwald, 2014; Telgen et al., 2016). As previously noted, corruption and malpractice related factors (i.e. Political interference and nepotism and Corruption and conflict of interest) as well as the lack of capacity (i.e. ineffective auditing, monitoring and evaluation) emerged as key inhibitors of public infrastructure procurement effectiveness. With respect to corruption, the findings reinforce reports that signal the widespread prevalence of these practices within the public sector in Nigeria as well as in other countries in sub-Saharan Africa (see Bowen et al., 2012; World Bank 2000; 2013; Fayomi, 2013; Adewole, 2014; Transparency International, 2017; Ameyaw et al., 2017). For 
instance, Transparency International's (2016) corruption perception index 2016 shows that sub-Saharan Africa is the worst region in terms of the perceived levels of public sector corruption.

Whereas the findings of the study pertain to Nigeria, they have overarching implications for developing country contexts, especially the sub-Saharan Africa region, where procurement practice and evolution has been established to be similar (Evenett and Hoekman, 2005; Ndercaj and Ringwald, 2014). Furthermore, there has been consistency in the findings of previous procurement related research, following the introduction reforms by governments and international institutions such as the World Bank over the past two decades (Telgen et al., 2016). These findings bring into focus the effectiveness of the model of procurement reforms adopted across the sub-Saharan African region, especially in relation to their effectiveness in dealing with corruption and malpractice as well as procurement capacity issues. The procurement reforms in several sub-Saharan African countries, including Nigeria have mainly been through the enactment of laws and the establishment of national level/centralised procurement regulatory bodies (Fayomi, 2013; Telgen et al., 2016). However, the findings of this study and others (e.g. Telgen et al., 2016) are symptomatic of a lack of complete effectiveness of the implementation of these reforms, particularly in tackling corruption, malpractice and capacity issues in public procurement. There is thus a need for an evaluation of the effectiveness of the approaches adopted for procurement reform across the sub-Saharan Africa region given the evidence from Nigeria and other similar contexts like Ghana (Ameyaw et al., 2017) and more generally developing countries (Neupane et al., 2012).

\section{CONCLUSIONS}


Whilst infrastructure is vital to the socio-economic development of countries, their effective procurement by public agencies can be fraught with challenges that pertain to an enabling national environment and its conduciveness for effective procurement. This study has examined the extent to which various external issues (30 environment level challenges) within this sphere of procurement capacity adversely impact on the effectiveness of infrastructure procurement by public agencies within Nigeria's local and state governance structure. In the main, the challenges examined by this study are perceived by procurement personnel as generally having a moderate impact. Nonetheless, challenges related to transparency, integrity, capacity and accountability are considered to be amongst the topmost challenges adversely affecting the effectiveness of infrastructure procurement by state and local government organisations. Interestingly, from this study, there is limited evidence to suggest that public procurement institutions across state and local government levels, and also across different geopolitical contexts experience these challenges at significantly different extents. This study also brings into focus the need for re-examination of the models of procurement reforms adopted in developing countries in view of the evidence from Nigeria.

In view of the above conclusions, the following recommendations are offered:

- Concerted, and sustained efforts by policy makers at various levels of government, public infrastructure procuring entities and civil society groups, are still needed to mitigate the effect of the procurement capacity challenges examined, in particular issues regarding transparency, integrity and accountability. Such efforts would benefit from coordination with public financial management systems, the legal and judiciary service, audit service, anti-corruption agencies, educational institutions, and the private sector, due to their interaction with capacity issues related to an enabling environment. 
- As procurement capacity is not static, but could improve or become worst, periodic assessment of the effect of capacity issues pertaining to an enabling national environment would be beneficial to policy formulators and implementers in gauging the state of health of the effectiveness of infrastructure procurement.

- Aligned to the above recommendation, the challenges examined in this study could be used in further procurement capacity assessment studies within other states in Nigeria, and indeed other national contexts, particularly in sub-Saharan Africa and other developing regions, where there are significant deficits in infrastructure and deficiencies in public procurement.

- Procurement reforms in sub-Saharan and other developing countries share some similarities in respect of the challenges that led to the reforms (e.g. corruption, malpractice and capacity issues) and approaches to the reforms (e.g. enactment of procurement legislation and establishment of central regulatory bodies). The findings of this study in respect of corruption and malpractice in public procurement ought to stimulate reviews of the effectiveness of the approaches to the procurement reforms in sub-Saharan and other developing countries.

- This study is solely based on a quantitative research approach involving a survey of public procurement personnel. As such, underlying reasons regarding the findings could not be explored in-depth. Further studies involving qualitative approaches could be worthwhile in unearthing further empirical realities.

\section{REFERENCES}

Addo-Duah, P., Westcott, T., Mason, J., Booth, C. A., and Mahamadu, A. (2014), "Developing capability of public sector procurement in Ghana: An assessment of the road subsector client", in Proceedings of Construction Research Congress 2014, 19-21 May 2014, Atlanta, American Society of Civil Engineers, USA. 
Adewole, A. (2014), "Governance reform and the challenge of implementing public procurement law regime across Nigerian state and local governments", International Journal of Public Administration and Management Research (IJPAMR), Vol. 2 No. 4, pp. 25-32.

Adewole, A. (2015), "Governance reform and public procurement law regime in Nigerian federating states: A case study of Oyo state", International Journal of Development and Economic Sustainability, Vol. 3 No. 1, pp. 18-29.

Adusei, C. and Awunyo-Vitor, D. (2015), "Implementation Challenges of the Public Procurement Act by Selected Metropolitan, Municipal and District Assemblies in the Ashanti Region, Ghana", iBusiness, Vol. 7, pp. 39-50.

AfDB (2013), "The infrastructure action plan for Nigeria: Closing the infrastructure gap and accelerating economic transformation: Summary Report", African Development Bank (AfDB), Tunis, Tunisia, available at: http://www.afdb.org/fileadmin/uploads/afdb/Documents/Project-andOperations/An_Infrastructure_Action_Plan_for_Nigeria__Closing_the_Infrastructure_Gap_and_Accelerating_Economic_Transformation.p df (access 1 March 2016).

Agu, C. and Onodugo, V. A. (2009), "Infrastructure services decentralisation for poverty reduction: Nigerian states", Journal of Infrastructure Development, Vol. 1 No. 2, pp. $153-178$.

Ahadzie, D. K., Proverbs, D. G., and Olomolaiye, P.O. (2008), "Critical success criteria for mass house building projects in developing countries", International Journal of Project Management, Vol. 26 No. 6, pp. 675-687.

Ameyaw, E. E., Pärn, E., Chan, A. P. C., Owusu-Manu, D.-G., Edwards, D. J. and Darko, A. (2017), "Corrupt practices in the construction industry: A survey of Ghanaian 
experience", Journal of Management in Engineering, Vol. 33 No. 6, pp. $05017006-$ 1-05017006-11.

BMPIU (2005), A manual on public procurement reform programme in Nigeria, State House, Abuja, Nigeria.

Bowen, P. A., Edwards, P. J., and Cattell, K. (2012), "Corruption in the South African construction industry: A thematic analysis of verbatim comments from survey participants", Construction Management and Economics, Vol. 30 No. 10, pp. 885901.

de Mariz, C. L. and Abeillé, B. (2014), Public procurement reforms in Africa: Challenges in institutions and governance, Oxford University Press, Oxford, UK.

Evenett, S. J. and Hoekman, B. (2005), International cooperation and the reform of public procurement policies (Policy Research Working Paper 3720). Washington, DC: World Bank.

Fayomi, I. O. (2013), "Public procurement and due process policy in Nigeria: Thrust, prospects and challenges", Peak Journal of Social Sciences and Humanities, Vol. 1 No. 4 , pp. 39-45.

Field, A. P. (2013), Discovering statistics using IBM SPSS statistic, $4^{\text {th }}$ edition, Sage Publications, Thousand Oaks, California, USA.

Foster, V. and Pushak, N. (2011), Nigeria's infrastructure: A continental perspective: Africa Infrastructure Country Diagnostic $(A I C D)$. Country Report, The International Bank for Reconstruction and Development - The World Bank, Washington, DC.

Jensen, K. R. E. and Refsgaard, M. L. (2008), "Procurement capacity development: From theory to practice", in Proceedings of the 3rd International Public Procurement Conference, August 28-30, 2008, Amsterdam, The Netherland, available at: http://www.ippa.org/IPPC3/Proceedings/Chaper\%2053.pdf (accessed 1 March 2016 
Jütting, J., Corsi, E., Kauffmann, C., Mcdonnell, I., Osterrieder, H., Pinaud, N. and Wegner, L. (2007), "What Makes Decentralisation in Developing Countries Propoor?" The European Journal of Development Research, Vol.17 No.4, pp 626-648. Kaduna State Government (2013), State development plan 2014-2018. Kaduna State Government, available at: http://www.sparcnigeria.com/RC/files/1.1.9_Kaduna_Development_Plan_2014_2018.pdf October 2016)

Kolstad, I. and Wiig, A. (2009), "Is transparency the key to reducing corruption in resource-rich countries?", World Development, Vol. 37 No. 3, pp. 521-532.

Ndercaj, V. and Ringwald, K. (2014), "An Investigation into the common challenges facing public sector procurement in sub-Saharan Africa", in $6^{\text {th }}$ Public Procurement Research Student Conference, April 28-29, Nottingham. UK.

Neupane, A., Soar, J., Vaidya, K. and Yong, J. (2012), "Role of public e-procurement technology to reduce corruption in government procurement", in Proceedings of the $5^{\text {th }}$ International Public Procurement Conference (IPPC5), August $17^{\text {th }}-19^{\text {th }}$ Seattle, WA. USA.

Ocheni, S. and Nwankwo, B. C. (2012), "Assessment of application of Due-Process Policy in public procurement and contracts under Obasanjo Administration in Nigeria, 2003-2007", International Business and Management, Vol. 5 No 1, pp. $93-$ 98.

OECD (2006), "The challenge of capacity development", Development Assistance $\begin{array}{llll}\text { Committee } & \text { (DAC) } \quad- & \text { OECD, available at: }\end{array}$ http://www.fao.org/fileadmin/templates/capacitybuilding/pdf/DAC_paper_final.pdf (access 1 March 2016).

OECD (2009), "Principles for integrity in public procurement", OECD, available at http://www.oecd.org/gov/ethics/48994520.pdf (access 20 July 2017). 
OECD and World Bank (2004), "Good practice paper on procurement capacity development", in The OECD Development Assistance Committee (DAC) - World Bank 3rd joint round table on strengthening procurement capacities in 24 developing countries, 30 November - 2 December 2004, Johannesburg, South Africa, World Bank, Washington, DC.

Olum, Y. (2014), "Decentralisation in developing countries: preconditions for successful implementation". Commonwealth Journal of Local Governance, Vol.15, pp. 23-38

Oyo State Government (2010), "Strategic health development plan (2010-2015)". Oyo State Government, available at: http://www.mamaye.org.ng/sites/default/files/evidence/Oyo\%20SSHDP\%2005.01. 11.pdf (access 28 January 2017).

Parente, S. and Prescott, E. (2000), Barriers to Riches, MIT Press, Cambridge, Massachusetts, USA.

Presidential Infrastructure Coordinating Commission (2012), "A summary of the South African national infrastructure plan", Presidential Infrastructure Coordinating Commission, South Africa, available at http://www.gov.za/issues/nationalinfrastructure-plan (accessed 22 February 2017).

Telgen, J., van der Krift, J., and Wake, A. (2016), Public procurement reform: Assessing interventions aimed at improving transparency. London: DFID.

Thai, V. K. (2001), "Public procurement re-examined", Journal of Public Procurement, Vol 1 No1, pp. 9-50.

Thai, V. K. (2005), "Challenges in public procurement", United Nations Procurement Capacity Development Centre, available at: http://www.unpcdc.org/media/4899/challenges\%20in\%20public\%20procurement.p df (accessed 21 March 2016). 
Transparency International (2017), “Corruption perceptions index 2016", Transparency International, Berlin, Germany, available at: https://www.transparency.org/whatwedo/publication/corruption_perceptions_index _2016 (accessed 27 July 2017).

UNDP (2006), Draft procurement capacity assessment user's guide, UNDP, New York. UNDP (2010), Public procurement capacity development guide, UNDP, New York.

United Nations Economic and Social Council (2016), "Progress towards the Sustainable Development Goals - Report of the Secretary-General", United Nations Economic and Social Council, available at: https://unstats.un.org/sdgs/files/report/2016/secretary-general-sdg-report-2016-EN.pdf (accessed 23 March 2017).

UNOPS (2014), “Procurement manual - Revision 5”, UNOPS, available at: http://www.unops.org/SiteCollectionDocuments/Procurement\%20docs/UNOPS\%2 Oprocurement\%20manual\%20EN.pdf (access 1 March 2016).

Veitch, C. (2014), "Infrastructure Industry in Nigeria", Who owns Who (Pty), South Africa, available at http://www.whoownswhom.co.za/public/sasector/report_content/Pages\%20from\% 20502\%20-\%20The\%20Infrastructure\%20Industry\%20Nigeria\%20\%20March\%202016\%20-\%20Contents.pdf (accesses 3 April 2016).

World Bank (1995), "Restoring urban Nigeria a strategy for restoring urban infrastructure and services in Nigeria", Report No. 45557, World Bank, Washington, DC, available at: http://documents.worldbank.org/curated/en/1995/12/10735837/restoring-urbannigeria-strategy-restoring-urban-infrastructure-services-nigeria (access 1 March 2016)

World Bank (2000), "Nigeria: country procurement assessment report (CPAR) Vol 1 Summary of findings and recommendations", Nigeria Country Department, World 
Bank, Africa available at: http://documents.worldbank.org/curated/en/2000/06/1121258/nigeria-countryprocurement-assessment-report-cpar (accessed 1 March 2016).

World Bank (2013), Nigeria Value Chain Analysis Study - A Study of Selected MDA's World Bank Africa Report Number ACS 1666, World Bank, Washington DC.

World Bank (2017), "Gross domestic product ranking table", World Bank, available online at http://data.worldbank.org/data-catalog/GDP-ranking-table (accessed 19 February 2017). 


\begin{tabular}{|c|c|c|c|c|c|c|c|c|c|c|}
\hline \multirow[t]{2}{*}{ Challenges } & \multicolumn{6}{|c|}{ Sources } & \multicolumn{4}{|c|}{$\begin{array}{l}\text { Categorisation of } \\
\text { challenges }\end{array}$} \\
\hline & 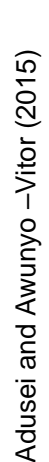 & 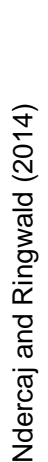 & 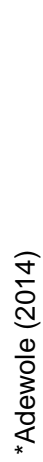 & 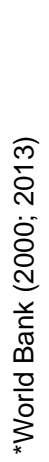 & 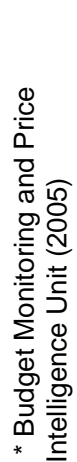 & 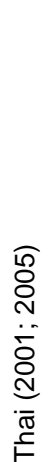 & 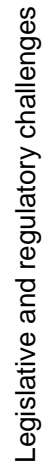 & 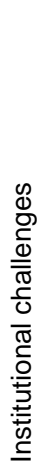 & 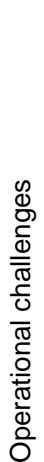 & 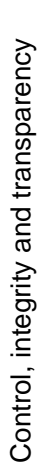 \\
\hline $\begin{array}{l}\text { Vague and outdated national procurement laws and } \\
\text { regulatory frameworks } \\
\text { Complexity and lack of detailed national regulations and } \\
\text { documentation on procurement } \\
\text { Inconsistencies among relevant Government documents } \\
\text { on procurement } \\
\text { Complicated procurement procedures for community } \\
\text { based and small size projects } \\
\text { Lack of consideration of social and environmental issues } \\
\text { in national procurement }\end{array}$ & $\sqrt{ }$ & $\begin{array}{l}\sqrt{ } \\
\sqrt{ } \\
\sqrt{ } \\
\sqrt{ } \\
\sqrt{ }\end{array}$ & & $\begin{array}{l}\sqrt{ } \\
\sqrt{ } \\
\sqrt{ } \\
\sqrt{ }\end{array}$ & & $\begin{array}{l}\sqrt{ } \\
\sqrt{ } \\
\sqrt{ } \\
\sqrt{ } \\
\sqrt{ }\end{array}$ & $\begin{array}{l}\sqrt{ } \\
\sqrt{ } \\
\sqrt{ } \\
\sqrt{ } \\
\sqrt{ }\end{array}$ & & & \\
\hline $\begin{array}{l}\text { Lack of capacity within regulatory institutions } \\
\text { General lack of capacity within other procuring } \\
\text { agencies/entities }\end{array}$ & $\sqrt{ }$ & $\sqrt{ }$ & & $\sqrt{ }$ & & $\begin{array}{l}\sqrt{ } \\
\sqrt{ }\end{array}$ & & $\sqrt{ }$ & & \\
\hline $\begin{array}{l}\text { Lack of capacity among procurement personnel in general } \\
\text { Lack of harmonization of procurement procedures } \\
\text { between donor partners, government and private } \\
\text { organisations }\end{array}$ & & $\sqrt{ }$ & & $\sqrt{ }$ & & $\sqrt{ }$ & $\sqrt{ }$ & $\sqrt{ }$ & & \\
\hline Centralized political and governance systems & & $\sqrt{ }$ & $\sqrt{ }$ & & & & & $\sqrt{ }$ & & \\
\hline Lack of leadership and political will for procurement reform & & $\sqrt{ }$ & $\sqrt{ }$ & $\sqrt{ }$ & & $\sqrt{ }$ & & $\sqrt{ }$ & & \\
\hline General lack of strategy and planning for procurement & & $\sqrt{ }$ & & $\sqrt{ }$ & & $\sqrt{ }$ & & $\sqrt{ }$ & & \\
\hline Socio-cultural disregard for laws and due process & & $\sqrt{ }$ & $\sqrt{ }$ & & & & & $\sqrt{ }$ & & \\
\hline Political interference and nepotism & $\sqrt{ }$ & $\sqrt{ }$ & $\sqrt{ }$ & $\sqrt{ }$ & & & & & & $\sqrt{ }$ \\
\hline $\begin{array}{l}\text { Lack of civil society participation } \\
\text { Lack of effective integration between national financial } \\
\text { management frameworks, government budgeting and } \\
\text { procurement }\end{array}$ & & $\sqrt{ }$ & $\sqrt{ }$ & $\sqrt{ }$ & $\sqrt{ }$ & $\sqrt{ }$ & & $\sqrt{ }$ & $\sqrt{ }$ & \\
\hline Poor access to information and lack transparency & $\sqrt{ }$ & $\sqrt{ }$ & & $\sqrt{ }$ & $\sqrt{ }$ & & & & & $\sqrt{ }$ \\
\hline Poor culture of record keeping & & $\sqrt{ }$ & & & & & & & $\sqrt{ }$ & \\
\hline Low capacity within private sector to participate & & $\sqrt{ }$ & & & & $\sqrt{ }$ & & $\sqrt{ }$ & & \\
\hline Corruption and conflict of interest & & $\sqrt{ }$ & $\sqrt{ }$ & $\sqrt{ }$ & & & & & & $\sqrt{ }$ \\
\hline $\begin{array}{l}\text { Ineffective auditing, monitoring and evaluation } \\
\text { Lack of knowledge and professionalism in public } \\
\text { procurement } \\
\text { Lack of harmonization of public procurement and other } \\
\text { legal or accountability systems }\end{array}$ & $\sqrt{ }$ & $\begin{array}{l}\sqrt{ } \\
\sqrt{ } \\
\sqrt{ }\end{array}$ & & $\sqrt{ }$ & $\sqrt{ }$ & $\sqrt{ }$ & & & & $\sqrt{ }$ \\
\hline $\begin{array}{l}\text { Lack of national procurement institutional integrity } \\
\text { Lack of educational and academic institutions for } \\
\text { procurement career development } \\
\text { Lack of motivation and job satisfaction in procurement } \\
\text { profession }\end{array}$ & & $\sqrt{ }$ & $\sqrt{ }$ & $\sqrt{ }$ & & $\sqrt{ }$ & & $\begin{array}{l}\sqrt{ } \\
\sqrt{ }\end{array}$ & & $\sqrt{ }$ \\
\hline Inadequate remuneration of procurement professionals & $\sqrt{ }$ & $\sqrt{ }$ & & $\sqrt{ }$ & & & & $\sqrt{ }$ & & \\
\hline $\begin{array}{l}\text { Lack of punishment for unethical behaviour } \\
\text { Lack of internationally recognized professional } \\
\text { certification programs or procurement courses }\end{array}$ & & $\sqrt{ }$ & & $\sqrt{ }$ & & $\sqrt{ }$ & & $\sqrt{ }$ & & $\sqrt{ }$ \\
\hline Poor knowledge transfer from donor/international projects & & & & $\sqrt{ }$ & & & & $\sqrt{ }$ & & \\
\hline
\end{tabular}

Notes: * Studies conducted in Nigeria. ${ }^{* *}$ Adapted from Ndercaj and Ringwald (2014) and OECD and World Bank (2004). 
Table 2: Respondents' Demographic Profile

\begin{tabular}{|c|c|}
\hline Demographic information & $\%$ of Respondents \\
\hline \multicolumn{2}{|l|}{ Respondent role } \\
\hline Engineer & 35.07 \\
\hline Quantity surveyor & 12.85 \\
\hline Administrator & 12.85 \\
\hline Architect & 8.33 \\
\hline Builder & 8.33 \\
\hline Estate surveyor & 5.21 \\
\hline Urban/town planner & 4.86 \\
\hline Land surveyor & 1.04 \\
\hline Purchasing officer/personnel & 1.04 \\
\hline Procurement officer/personnel & 4.17 \\
\hline Other roles & 6.25 \\
\hline \multicolumn{2}{|l|}{ Experience in role (in years) ${ }^{a}$} \\
\hline $0-5$ & 16.32 \\
\hline $6-10$ & 23.96 \\
\hline $11-15$ & 21.88 \\
\hline $15-20$ & 18.40 \\
\hline Over 20 & 14.93 \\
\hline \multicolumn{2}{|l|}{$\begin{array}{l}\text { Experience in procurement of infrastructure (in years) }{ }^{a} \\
0-5\end{array}$} \\
\hline $6-10$ & 30.21 \\
\hline $11-15$ & 10.76 \\
\hline $15-20$ & 6.94 \\
\hline Over 20 & 5.21 \\
\hline \multicolumn{2}{|l|}{ Type of Infrastructure ${ }^{b}$} \\
\hline Housing infrastructure & 37.85 \\
\hline Power generation and electricity infrastructure & 26.04 \\
\hline Education infrastructure & 23.26 \\
\hline Transport infrastructure & 19.79 \\
\hline Water and sanitation infrastructure & 15.97 \\
\hline Health infrastructure & 7.29 \\
\hline \multicolumn{2}{|l|}{ Type of organization } \\
\hline State government & 47.92 \\
\hline \multicolumn{2}{|l|}{ Location } \\
\hline South & 59.38 \\
\hline North & 40.63 \\
\hline
\end{tabular}

Note: ${ }^{a}$ Due to non-response by some respondents the total $\%$ is less than $100 \%$.

${ }^{b}$ Due to involvement in procurement of multiple infrastructure type, total is greater than $100 \%$ 
Table 3: Effect of Procurement Capacity Challenges on Effectiveness of Infrastructure Procurement

\begin{tabular}{|c|c|c|c|c|c|c|c|c|c|c|c|c|}
\hline \multirow{3}{*}{ Challenges } & \multirow{3}{*}{$\mathrm{N}$} & \multirow{3}{*}{ Mean } & \multirow{3}{*}{$\begin{array}{l}\text { Rank } \\
\text { by } \\
\text { Mean }\end{array}$} & \multirow{3}{*}{$\begin{array}{l}\text { Std. } \\
\text { Dev. }\end{array}$} & \multirow{3}{*}{$\begin{array}{l}\text { Std. } \\
\text { Error } \\
\text { Mean }\end{array}$} & \multicolumn{7}{|c|}{ One Sample t-Test $($ Test value $=2.5)$} \\
\hline & & & & & & \multirow{2}{*}{$\mathrm{t}$} & \multirow{2}{*}{$\mathrm{df}$} & \multirow{2}{*}{$\begin{array}{l}\text { Sig. }(2- \\
\text { tailed) }\end{array}$} & \multirow{2}{*}{$\begin{array}{l}\text { Sig. }(1- \\
\text { tailed) }\end{array}$} & \multirow{2}{*}{ Mean Diff. } & \multicolumn{2}{|c|}{$\begin{array}{l}95 \% \text { Confidence } \\
\text { Interval of the } \\
\text { Difference }\end{array}$} \\
\hline & & & & & & & & & & & Lower & Upper \\
\hline Political interference and nepotism & 287 & 3.561 & 1 & 1.088 & 0.064 & 16.517 & 286 & 0.000 & 0.000 & 1.061 & 0.935 & 1.187 \\
\hline Corruption and conflict of interest & 286 & 3.545 & 2 & 1.147 & 0.068 & 15.415 & 285 & 0.000 & 0.000 & 1.045 & 0.912 & 1.179 \\
\hline $\begin{array}{l}\text { Inadequate remuneration of procurement } \\
\text { professionals }\end{array}$ & 285 & 3.414 & 3 & 1.158 & 0.069 & 13.320 & 284 & 0.000 & 0.000 & 0.914 & 0.779 & 1.049 \\
\hline Ineffective auditing, monitoring and evaluation & 287 & 3.376 & 4 & 1.161 & 0.069 & 12.789 & 286 & 0.000 & 0.000 & 0.876 & 0.741 & 1.011 \\
\hline Poor access to information and lack transparency & 285 & 3.375 & 5 & 1.118 & 0.066 & 13.222 & 284 & 0.000 & 0.000 & 0.875 & 0.745 & 1.006 \\
\hline $\begin{array}{l}\text { Lack of motivation and job satisfaction in } \\
\text { procurement profession }\end{array}$ & 287 & 3.366 & 6 & 1.144 & 0.068 & 12.817 & 286 & 0.000 & 0.000 & 0.866 & 0.733 & 0.999 \\
\hline Lack of civil society participation & 286 & 3.364 & 7 & 1.105 & 0.065 & 13.214 & 285 & 0.000 & 0.000 & 0.864 & 0.735 & 0.992 \\
\hline $\begin{array}{l}\text { Lack of knowledge and professionalism in public } \\
\text { procurement }\end{array}$ & 287 & 3.355 & 8 & 1.155 & 0.068 & 12.543 & 286 & 0.000 & 0.000 & 0.855 & 0.721 & 0.990 \\
\hline Socio-cultural disregard for laws and due process & 286 & 3.346 & 9 & 1.097 & 0.065 & 13.049 & 285 & 0.000 & 0.000 & 0.846 & 0.719 & 0.974 \\
\hline Centralized political and governance systems & 287 & 3.314 & 10 & 1.054 & 0.062 & 13.076 & 286 & 0.000 & 0.000 & 0.814 & 0.691 & 0.936 \\
\hline Poor culture of record keeping & 286 & 3.301 & 11 & 1.176 & 0.070 & 11.515 & 285 & 0.000 & 0.000 & 0.801 & 0.664 & 0.938 \\
\hline $\begin{array}{l}\text { Lack of leadership and political will for } \\
\text { procurement reform }\end{array}$ & 287 & 3.300 & 12 & 1.144 & 0.068 & 11.843 & 286 & 0.000 & 0.000 & 0.800 & 0.667 & 0.933 \\
\hline $\begin{array}{l}\text { General lack of strategy and planning for } \\
\text { procurement }\end{array}$ & 287 & 3.300 & 12 & 1.110 & 0.066 & 12.207 & 286 & 0.000 & 0.000 & 0.800 & 0.671 & 0.929 \\
\hline Low capacity within private sector to participate & 287 & 3.293 & 14 & 1.124 & 0.066 & 11.946 & 286 & 0.000 & 0.000 & 0.793 & 0.662 & 0.923 \\
\hline Lack of punishment for unethical behaviour & 286 & 3.290 & 15 & 1.183 & 0.070 & 11.296 & 285 & 0.000 & 0.000 & 0.790 & 0.653 & 0.928 \\
\hline
\end{tabular}


Lack of effective integration between national financial management frameworks, government budgeting and procurement

Inconsistencies among relevant Government documents on procurement (Acts and Regulations)

Lack of harmonization of public procurement and other legal or accountability systems

Poor knowledge transfer from donor/international projects

Complicated procurement procedures for community based and small size projects

Lack of internationally recognized professional certification programs or procurement courses

Lack of educational and academic institutions for procurement career development

Lack of harmonization of procurement procedures between donor partners, government and private organisations

Lack of national procurement institutional integrity

Lack of capacity among procurement personnel in general

General lack of capacity within other procuring agencies/entities

Lack of capacity within regulatory institutions

Complexity and lack of detailed national

regulations and documentation on procurement

\begin{tabular}{|c|c|c|c|c|c|c|c|c|c|c|c|}
\hline 285 & 3.277 & 16 & 1.086 & 0.064 & 12.079 & 284 & 0.000 & 0.000 & 0.777 & 0.651 & 0.904 \\
\hline 287 & 3.272 & 17 & 1.062 & 0.063 & 12.307 & 286 & 0.000 & 0.000 & 0.772 & 0.648 & 0.895 \\
\hline 286 & 3.262 & 18 & 1.052 & 0.062 & 12.255 & 285 & 0.000 & 0.000 & 0.762 & 0.640 & 0.885 \\
\hline 287 & 3.254 & 19 & 1.138 & 0.067 & 11.229 & 286 & 0.000 & 0.000 & 0.754 & 0.622 & 0.887 \\
\hline 287 & 3.230 & 20 & 1.095 & 0.065 & 11.295 & 286 & 0.000 & 0.000 & 0.730 & 0.603 & 0.857 \\
\hline 287 & 3.230 & 20 & 1.258 & 0.074 & 9.828 & 286 & 0.000 & 0.000 & 0.730 & 0.584 & 0.876 \\
\hline 286 & 3.227 & 22 & 1.197 & 0.071 & 10.277 & 285 & 0.000 & 0.000 & 0.727 & 0.588 & 0.867 \\
\hline 287 & 3.213 & 23 & 1.131 & 0.067 & 10.670 & 286 & 0.000 & 0.000 & 0.713 & 0.581 & 0.844 \\
\hline 287 & 3.209 & 24 & 1.089 & 0.064 & 11.026 & 286 & 0.000 & 0.000 & 0.709 & 0.582 & 0.836 \\
\hline 286 & 3.203 & 25 & 1.093 & 0.065 & 10.878 & 285 & 0.000 & 0.000 & 0.703 & 0.576 & 0.830 \\
\hline 284 & 3.194 & 26 & 1.040 & 0.062 & 11.235 & 283 & 0.000 & 0.000 & 0.694 & 0.572 & 0.815 \\
\hline 287 & 3.167 & 27 & 1.081 & 0.064 & 10.461 & 286 & 0.000 & 0.000 & 0.667 & 0.542 & 0.793 \\
\hline 287 & 3.139 & 28 & 1.058 & 0.062 & 10.233 & 286 & 0.000 & 0.000 & 0.639 & 0.516 & 0.762 \\
\hline
\end{tabular}


Lack of consideration of social and environmenta issues in national procurement frameworks and regulations

Vague and outdated national procurement laws and regulatory frameworks 
Table 4: Differences in Perceived Effect of Procurement Capacity Challenges Related to an Enabling Environment - By Type of Respondents'

Organization

\begin{tabular}{|c|c|c|c|c|c|c|c|c|c|c|c|c|c|c|c|}
\hline \multirow{3}{*}{ Challenges } & \multirow{3}{*}{$\begin{array}{l}\text { Organization } \\
\text { Type }\end{array}$} & \multirow{3}{*}{$\mathrm{N}$} & \multirow{3}{*}{ Mean } & \multirow{3}{*}{$\begin{array}{l}\text { Std. } \\
\text { Dev. }\end{array}$} & \multirow{3}{*}{$\begin{array}{l}\text { Std. } \\
\text { Error } \\
\text { Mean }\end{array}$} & \multicolumn{10}{|c|}{ Independent Samples t-test for Equality of Means } \\
\hline & & & & & & \multicolumn{3}{|c|}{$\begin{array}{c}\text { Levene's Test for Equality of } \\
\text { Variances }\end{array}$} & \multirow[t]{2}{*}{$\mathrm{t}$} & \multirow[t]{2}{*}{ df } & \multirow[t]{2}{*}{$\begin{array}{c}\text { Sig. } \\
(2- \\
\text { tailed })\end{array}$} & \multirow[t]{2}{*}{$\begin{array}{l}\text { Mean } \\
\text { Diff. }\end{array}$} & \multirow[t]{2}{*}{$\begin{array}{l}\text { Std. } \\
\text { Error } \\
\text { Diff. }\end{array}$} & \multicolumn{2}{|c|}{$\begin{array}{l}95 \% \text { Confidence } \\
\text { Interval of the } \\
\text { Difference } \\
\end{array}$} \\
\hline & & & & & & $\begin{array}{l}\text { Equality of } \\
\text { Variance }\end{array}$ & $\mathrm{F}$ & Sig. & & & & & & Lower & Upper \\
\hline $\begin{array}{l}\text { Lack of knowledge and } \\
\text { professionalism in public } \\
\text { procurement }\end{array}$ & $\begin{array}{l}\text { Local } \\
\text { government } \\
\text { State } \\
\text { government }\end{array}$ & 137 & 3.493 & 1.180 & $\begin{array}{l}0.096 \\
0.095\end{array}$ & $\begin{array}{l}\text { Equal } \\
\text { variances } \\
\text { assumed } \\
\text { Equal } \\
\text { variances not } \\
\text { assumed }\end{array}$ & 1.683 & 0.196 & 2.129 & 285.000 & 0.034 & 0.289 & $\begin{array}{l}0.136 \\
0.135\end{array}$ & 0.022 & 0.556 \\
\hline
\end{tabular}

Notes: Scale $-1=$ not at all; $2=$ low; $3=$ moderate $4=$ high $; 5=$ very high 